\title{
Fish Cultivation as a Livelihood Option for Small Scale Farmers - Study in Southwestern Region of Bangladesh
}

\author{
Nurun Naher Moni ${ }^{1}$, Nawshin Neelam Khan ${ }^{2}$ \\ ${ }^{I}$ (Assistant Professor, Economics Discipline, Khulna University, Khulna-9208, Bangladesh) \\ ${ }^{2}$ (Economics Discipline, Khulna University, Khulna-9208, Bangladesh)
}

\begin{abstract}
Present study explores the importance of fish farming in the livelihood of small scale fish farmers of Batiaghata upazila in the Southwestern region of Bangladesh. This is an exploratory type study, which selects three villages of Batiaghata upazila. It collects primary data from 30 fish cultivators through questionnaire survey and key informant interview method. The study findings show that fish cultivation is the main occupation for 56.67 percent of the farmers. It has an important implication for ensuring emergency cash flow in terms of urgent medical expenses, financing children's education and supporting household economy in times of maintaining social and family occasions. It also alters households' protein consumption level and income, expenditure and savings pattern of the households. Recognizing the importance of small scale fish farming in the region, present study suggest government and non government organizations ensuring efficient marketing, expanding training program and ensuring supply of quality fish fry and fingerlings.
\end{abstract}

Keywords: Household economy, Small scale fish farming, Sustainable livelihood

\section{Introduction}

Being the largest delta in the world, Bangladesh is favoured by numerous rivers and its tributaries. Abundance of water bodies in the Southwestern coastal region integrates the lives and livelihoods of a greater number of people with fisheries sector. Therefore, livelihood of the people in the Southwestern coastal region of Bangladesh is virtually dependent on the fisheries sector. Fisheries sector comprises both shrimp and non shrimp sector in that region; both of them demands utmost priority while measuring GDP contribution to the national economy. Fisheries sector contributes 5.71 percent of total export earning and 4.92 percent to the GDP. The sector contributes 22 percent of total agricultural production \& 63 percent of the total animal protein intake of the country [1]. This sector provides employment to about 4.27 million households, which comprises 20 percent of rural inhabitants. They produce fish in their small pond, covering a combined area of 265,000 hectare [2].

Different varieties of fish resources are harvested in Bangladesh. There are about 795 native species of fish and shrimp in the fresh and marine water of Bangladesh and 12 exotic species. In addition, there are 10 species of pearl bearing bivalves, 12 species of edible tortoise and turtle, 15 species of crab and 3 species of lobster [3]. Bangladesh produces 1308 thousand tones of fisheries, which is 2.19 percent of total world aquaculture production and occupies fifth position after China, India, Vietnam and Indonesia [4]. Apart from serving the local demand, a lot of people in rural areas are engaged in freshwater fish cultivation. Besides this, fish is a rich source of animal protein. Fish culture contributes to improve the nutritional standards of the people. It also helps in utilizing water and land resources. It provides an inducement to establish other subsidiary industries in the country.

It is important to note that fisheries sector plays an important role in the national economy of Bangladesh. Fisheries sector in Bangladesh can be broadly divided into four major sub-sectors: inland capture or open-water fisheries, inland culture or closed-water fisheries, marine industrial (trawling) fisheries and marine artisanal fisheries. The inland fisheries contribute about 80.59 percent of the total catch and the remaining 19.4 percent comes from the marine fisheries [1].

The production of fish from pond fish culture is increasing rapidly in Bangladesh in spite of the fact that its total production is still less than that of inland open water capture fisheries [5]. Bangladesh produces $1,400,000$ tons of fish annually mostly through inland capture fisheries and aquaculture. Emphasis has always been laid on the improvement and expansion of the aquaculture sector, which received around 60 percent of the donor funding over the period 1986- 2005 [6]. Bangladesh has extensive and highly diversified fisheries resources. Department of Fisheries (DOF) statistics estimates that total fish production in Bangladesh is 2.56 million tones, of which aquaculture accounts for 39 percent [2].

Fisheries sector plays an important role in nutrition, income, employment and export earnings in Bangladesh. In the Bangladeshi food diet fish plays a vital role, which provides more than 60 percent of animal protein. Fish is the second most important agricultural crop. Millions of peoples' livelihood and employment is 
related with this sector [2]. It plays particularly an important role among disadvantaged groups as a main or supplementary source of employment, livelihood and income. Most of the Bangladeshi poor live in rural areas with very limited employment opportunities. The Poverty Reduction Strategy Paper (PRSP) and National Fisheries Strategy of Bangladesh government indicated that income-generating opportunities for rural households are most promising in the fisheries sector ([7] as cited in [8]). In addition to this, fishes contribute to 63 percent of animal protein intake, about 5 percent of gross domestic product and 5 percent of export earnings; approximately 1.4 million people are directly engaged in fishing, 11 million in part-time fishing and another 3 million in aquaculture activities [9].

Fish trade is a significant source of foreign currency earnings for Bangladesh and delivers benefits at both the macro and microeconomic levels. Fish is the third largest contributor to Bangladesh's export earnings and it is growing annually by 5-8 percent. Revenue from traditional exports of non-fish agricultural products are gradually being outpaced by fishery products. Now fish has become the most important primary commodity that Bangladesh exports [8].

Rahman et al. [10] reported that fish farming has considerable contribution on household income of the farmers. They conclude that policy makers in the fisheries sector should consider the recognized factors for rapid growth of fish farming in rural Bangladesh. Hossain et al. [11] conducted a survey of socioeconomic condition of the landowners (LO) and landless (LL) fishermen group who fully or partly depend on fishing activities in two seasonal floodplain beels in Rajshahi district of Bangladesh in the year 2006-2007. They found that the average annual household income of the LO fishermen ranges from Tk. 77396-96888 whereas average annual household income of the LL fishermen ranges from Tk. 36407-37990 which is much below the poverty line. Agriculture is the main occupation and aquaculture, fish trade and business are the main secondary occupations for the LO farmers. Average fish consumptions for all types of farmers are $1.38 \mathrm{~kg} / \mathrm{capita} / \mathrm{month}$. They think that fish culture can improve their socioeconomic condition. The fishermen need to be educated and trained to actively participate to productivity enhancing activities in these seasonal floodplain aquatic ecosystems.

Chowdhury and Maharjan [5] argued that the problems faced by the fishermen are multiple ownership of pond, multiple use of pond water, lack of technical know how, non availability of quality fish seed, lack of pesticide, lack of experience, fish disease etc. Among them, capital deficiency is the main problem. They also showed that people's participation in pond fishery development through Comprehensive Village Development Program (CVDP) approach offers some advantages to the government, development agencies as well as rural inhabitants which increase in productivity, efficiency and cost effectiveness and sustainability.

Sarker et al. [12] in their study identified the major barriers of pond fish culture entrepreneurships in Bangladesh. Needed data were collected with questionnaire by personal interviewing of the respondents. Result shows that lack of technical knowledge on pond management, unavailability of credit, poor extension service and lack of information has been identified as the barriers of pond fish culture entrepreneurships. Findings of their study also show that there are negative significant relationships of education, income from pond fish culture, availability of information sources and knowledge on pond fish culture with the barriers of pond fish culture entrepreneurships. Age and family size have positive significant relationships with the barriers of pond fish culture entrepreneurships. However, the results of stepwise multiple regression indicates that 65.4 percent (Adjusted $\mathrm{R}^{2}=0.654$ ) of the variance in the barriers of pond fish culture entrepreneurships could be explained by the explanatory variables of the study.

Fresh water fish cultivation is no less emphasized than shrimp cultivation in the Southwestern coastal region of Bangladesh. This research work is based on small scale fish farming and its impact on the fish cultivators' families. In Batiaghata upazila, fish cultivation is the second major occupation after cropping and it has become one of the important sources of livelihood for the people of that area. It is important to note that while discussing fisheries sector of the Southwestern coastal region of Bangladesh, shrimp aquaculture draws special attention due to its' spectacular growth and high economic premiums. Apart from a number of positive effects, shrimp aquaculture has serious environmental and ecological concerns. In addition, it has created livelihood displacement followed by socio-economic vulnerability of the poor [13]. Possibility of expansion of freshwater fisheries and proper utilization of aquatic resources in turn have largely been overlooked and neglected in the region. Within this backdrop, present study attempts to explore the contribution of small scale fish farming to ensure sustainable livelihood for the households. In addition to this, it also tries exploring the potentiality of freshwater fish farming in the study area.

\section{Materials and Methods}

For this research work, Jalma union of Batiaghata upazila has been selected purposively because most of the people in that area are related with fish cultivation. Three out of 33 villages in Jalma union named Mohammadnagar, Sachibunia and Kochubunia were surveyed for this study. Batiaghata upazila of Khulna district with an area of $248.33 \mathrm{sq} \mathrm{km}$, is bounded by Kotwali (Khulna), Dumuria and Rupsa upazila and 
Sonadanga thana on the north, Dumuria upazila and Paikgachha upazila on the west, Dacope, Paikgachha and Rampal upazila on the south, Rampal, Fakirhat and Rupsa upazila on the east. The main rivers are Kazibachha, Shoilmari, Salta, Jhopjhopia, Pasur, Sibsa, Rupsa and Nalua [14].

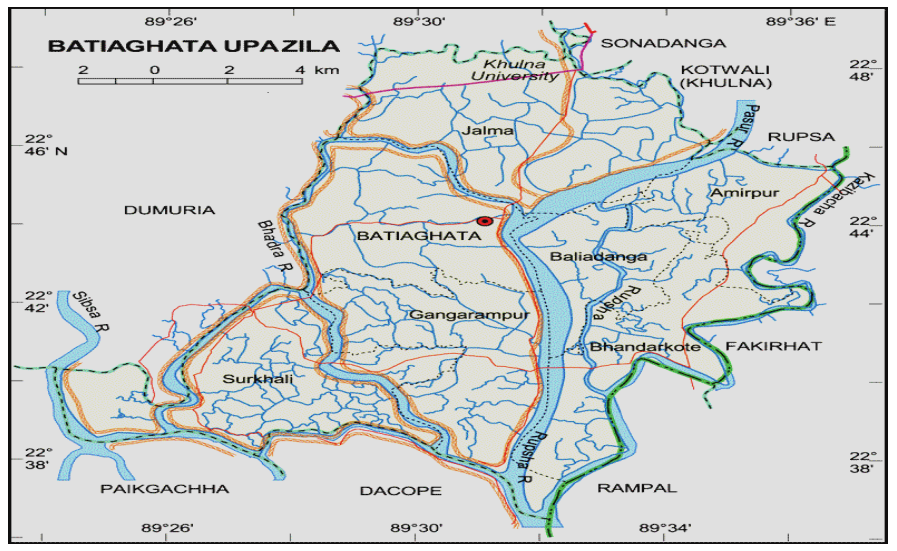

Figure 1: Map of Batiaghata upazila

The study is qualitative in nature. All the aspects are briefly described and an in-depth analysis of all the variables with before-after method has been shown in the study. Total population of Jalma union is approximately 59,025. Nearly 750 people are related with commercial fish production in three selected villages of Jalma union. Therefore, the study has the sampling frame with 750 fish cultivators. Out of these fish cultivators, randomly selected 30 fish cultivator households, 10 households from each of the village were surveyed for the research work.

To find out information about the socio-economic condition before involving in fish cultivation and after starting fish cultivation, as well as to identify problems and prospects of fish cultivation, data were collected through interview method. To get more specific and reliable data, the survey was carried out by personal interview with the help of semi-structured questionnaire. The main socio economic variables included in the questionnaire were family size, age distribution, educational status, ownership of housing, pond and fishing equipments, health status, fish consumption, family income and expenditure, training and experience of the fish farmers etc. In addition to this, key informant interview was carried out to collect data on production, pond management, and to explore the potentiality of fish farming in the study area.

For this study, secondary data was needed for conceptualization of various issues and literature review. Different published reports, related articles, organization reports and government databases were the main secondary sources. Data on different issues like number of schools, colleges, situation of electricity, area of total water bodies, nature of fish farming, total amount of fish produced in the upazila etc. were also collected from different government organizations, which are Union Parishad Office, Upazila fisheries office, Department of Statistics and also from Non Government Organizations (NGOs).

Collected data were sorted, processed and analyzed to make it suitable for the study. After that it was interpreted according to the objectives. Proper attention was given to eliminate biased and incomplete information. To increasing reliability of data, it was crosschecked with appropriate agents. Finally the study tries to concise the findings of the research.

\section{Fish Cultivation in Batiaghata Upazila}

In order to explore the contribution of fish farming to the socio-economic status of the households, the study selects three villages of Jalma union of Batiaghata upazila, which are Mohammadnagar, Sachibunia and Kochubunia. Although most of the people of these three villages are primarily dependent on agriculture, fish cultivation offers a gainful employment opportunity and source of income for the people. Availability of a greater number of rivers, ponds and other natural and manmade water bodies in this region provide an inducement to maintaining their livelihood based on fishing. Batiaghata upazila is crisscrossed by a number of small and big rivers, which are Kazibachha, Shoilmari, Salta, Jhopjhopia, Pasur, Sibsa, Rupsa and Nalua. Total number of ponds in this upazila is 5001, which is far greater than many other parts of Southwestern region. It is important to note that this area is not affected by salinity intrusion, which offers an extra advantage to fresh water fish cultivation. This area is one of the major suppliers of various kinds of fresh water fishes, which are vetki (Lates calcarifer), parshe (Liza parsia), khorsuna (Rhinomugil corsula), bele (Glossogobius giuris), ruhi (Labeo rohita), katla (Catla catla), mrigel (Cirrhinus cirrhosus), kalibaush (Labeo calbasu), mirror carp (Cyprinus carpio), thai sorputi (Puntius sarona), thai pangas (Pangasius pangasius), thai koi (Anabus testudineus), tilapia (Oreochromis mossambicus), crab, nona tengra (Batasio batasio), topse jaba, tulor dati, 
datina (Aconthopagrus datina), vangon, bata (Labeo bata), maya chela (Amblypharyngodon mola), puti(Puntius puntio). Total production of fish in this region is sufficiently large to meet the local demand and nearby district demand. After fulfilling the local demand, this area exports a little amount of thai pangas, ruhi, katla, mrigel, vetki and parshe to the international market. Fish cultivation in this region also ensures appropriate land use by combining fish cultivation with rice for about 11 percent of double cropped land. In this upazila, total cultivation land is 18494.53 hectares of which 60.70 hectares are fallow land [14]. Fish farming combined with paddy cultivation provides an enormous potential to expand fish cultivation in that fallow land. Following table shows an overview of fisheries sector in that region:

Table 01: An Overview of Fisheries Sector in Batiaghata upazila in Year 2012

\begin{tabular}{|c|c|c|c|}
\hline Activities & Number & Area (hectare) & Production (Mt) \\
\hline \multicolumn{4}{|l|}{ Pond } \\
\hline Government & 03 & 1.26 & 2.65 \\
\hline Non government & 4998 & 451 & 932 \\
\hline Total & 5001 & 452.26 & $\begin{array}{l}\left.924.0 \text { (white fish }{ }^{1}\right) 34.65 \\
\text { (shrimp) }\end{array}$ \\
\hline \multicolumn{4}{|l|}{ Nongovernment fish farm (commercial) } \\
\hline Small (1-2 ha) & 25 & 25 & 107.0 \\
\hline Medium (2-4 ha) & 15 & 30 & 815.0 \\
\hline Large (4+ ha) & 05 & 50 & 1622.0 \\
\hline Total & 45 & 105.0 & 2544.0 \\
\hline \multicolumn{4}{|l|}{ Paddy with fish } \\
\hline With paddy & 12 & 2.36 & 1.07 \\
\hline After paddy & 0 & 0 & 0 \\
\hline Total & 12 & 2.36 & 1.07 \\
\hline $\begin{array}{l}\text { Water bodies of Bangladesh Water } \\
\text { Development Board }\end{array}$ & 45 & 82.14 & $\begin{array}{l}42.5 \text { (white fish) } \\
22.2 \text { (shrimp) }\end{array}$ \\
\hline \multicolumn{4}{|l|}{ Paddy-shrimp mixed farming } \\
\hline Golda with paddy & 25 & 7.0 & 5.60 (white fish), 2.45 (golda) \\
\hline Golda after paddy & 5395 & 1840.0 & 1202 (white fish), 1001.4( golda) \\
\hline Bagda after paddy & 2610 & 1715.0 & 677.5 (white fish), 462.2 (bagda) \\
\hline Total & 8030 & 3562 & $\begin{array}{l}1885.1 \text { (white fish), } 1466.5 \\
\text { (shrimp) }\end{array}$ \\
\hline Non government golda mixed farming & 5395 & 1840.0 & $\begin{array}{l}\text { 1202.0 (white fish), } 1001.4 \\
\text { (shrimp) }\end{array}$ \\
\hline & & & \\
\hline
\end{tabular}

Source: (FOBUP) [15]

The Table above shows that in the year 2012, white fish production occupies the dominant portion among all categories of fish farming in that region. Geographical setting, which includes numerous rivers, ponds, ditches and other water bodies ensures a competitive edge of white fish production over shrimp production in that region. Another important feature is that this area has a wide practice of mixed farming system of different types. For example, combining paddy and golda; paddy and bagda; golda and white fish; paddy and white fish. Among them, in terms of quantity, cultivating golda after paddy and golda with white fish occupy the dominant position followed by bagda after paddy cultivation.

In the study area, fish cultivation offers major occupation for 56.67 percent of the respondents. For the rest 43.33 percent, it is the second major occupation. Field survey shows that benefits derived from fish cultivation depends on a set of socio-economic factors, which includes household's access to credit market and willingness to participate in the credit market, experience of fish farming, training, number of income earners within the family and households' ownership of asset and households' willingness and capacity to participate in the fish market. Due to the degree and magnitude of these determinants, different income groups affected differently from fish cultivation. For all of the cases, income from fish farming contributes importantly in savings and expenditure pattern and ensuring emergency cash flow of the households. Present study is an attempt to address that contribution of small scale fish farming to maintain sustainable livelihood of the households.

\subsection{Socio-economic Status of the Respondents}

Field survey shows that 33.33 percent of the respondents belong to the age group of 36-45, which occupies the dominant portion. Second major group is $46-55$, where 26.67 percent of the respondents belong to. Again 20 percent of the respondents belong to the age group of 56-65. Another 20 percent of the respondents are observed in the age group of $15-25$. It is observed that 80 percent of the respondents' age in the study area is

\footnotetext{
${ }^{1}$ White fish means fresh water fish
} 
above 25 years. Again 40 percent of the respondent comes from nuclear family and rest 60 percent comes from joint family. In case of educational status , 13.33 percent can only sign, 20 percent have 5 years of formal schooling, 50 percent of the respondents have 10 years of formal schooling (secondary school education), and rest 16.67 percent have 12 years formal schooling. Greater number of fish cultivators with secondary school education proves that without any exception, fish cultivation requires a minimum level of education to acquire skill and knowledge regarding fish farming.

With regard to housing pattern, 46.67 percent live in kancha houses, 33.33 percent live in semi-pucca houses and rest 20 percent live in pucca houses. Not all the respondents in the study area have own ponds. Only 56.67 percent have own ponds and 43.33 percent have rented ponds. For rented ponds, farmers have to pay money or certain amount of fishes. Like ponds, almost 77 percent have fishing equipments like nets, drum, fishhook, and bucket etc. of their own. Rest 23 percent have to rent their equipments from other sources.

Majority of the respondents in the study area do not have any formal training, which comprises 56.67 percent respondents. They receive informal training from local fish farmers through coming close touch with them. Rest 43.33 percent have formal training given by different NGOs, for example, Sushilon, BRAC and WorldFish Center. Duration of training in this case ranges from 15 days to three months. Various government and non government organizations are the main sources of credit in the study area. 30 percent of the respondents take credit from Bangladesh Rural Development Board (BRDB), BRAC and from Grameen Bank. Among the recipients, 33.34 percent have taken credit Tk. 5001-10000. Then Tk. 10001-15000 and Tk. 0-5000 are taken by 22.22 percent of the respondents for each group respectively. Again Tk. 15001-20000 and Tk. 20001+ have been taken by 11.11 percent of the respondents for each group. Almost 70 percent respondents did not take credit because most of them are small scale fish cultivators whose investment in fish farming is small and flexible in nature. Therefore, they rely on their own sources and other informal sources form friends and relatives in case of financial urgency.

\section{Fish Cultivation as a Sustainable Livelihood Option}

Two types of fish farming have been practiced in the study area. First type is pond fish culture, which has been practiced by 77 percent of the respondents. Second type in the study area is mixed farming (in the village Sachibunia), which combines paddy with fish and are done by 33 percent farmers. Pond fish culture is to be regarded as small scale fish cultivation in terms of pond size, investment, intensity of cultivation and volume of production. Lowest pond size in the study area is 0.124 acre and highest pond size is 1.70 acre. Average pond size is 0.33829 acre. In terms of gross production, they produce a smaller volume of fishes mainly for subsistence requirement and meeting emergency demand in times of household's need, although 80 percent of the respondents sell 70 to 75 percent of their total product in the market. Rest 20 percent produce fishes only for their own consumption. Following table summarizes the amount of fish production of the respondents:

Table 02: Production of Fish

\begin{tabular}{|c|c|c|}
\hline & Kg/year & Percentage of respondents \\
\hline & $<100$ & 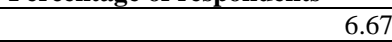 \\
\hline & $101-500$ & 33.33 \\
\hline & $501-1000$ & 6.67 \\
\hline & $1001-1500$ & 26.67 \\
\hline & $1501-2000$ & 13.33 \\
\hline & $2000<$ & 13.33 \\
\hline & Total & 100 \\
\hline
\end{tabular}

Source: Author's calculation based on field survey

Table 02 shows that only 6.67 percent of the respondents produce less than $100 \mathrm{~kg}$ of fish per year. Highest percentage of respondents, which is 33.33 percent, produces 101 to $500 \mathrm{~kg}$ fish per year. Then second highest group is 26.67 percent, who produces $1001 \mathrm{~kg}$ to $1500 \mathrm{~kg}$ fish per year. Then $1501 \mathrm{~kg}$ to $2000 \mathrm{~kg}$ and more than $2000 \mathrm{~kg}$ of fish have been produced by 13.33 percent of respondents for each group.

Another important feature of this type of farming is that the farms locate either inside their homesteads or very much adjacent to their homestead lands. Fish cultivators try to live near the pond/ gher ${ }^{2}$ because it is helpful for them to manage the farm. In some cases ponds/ghers are in distant places. Maximum distance of the gher is four kilometer away from the farmer's house. Due to nearness of the pond/gher, the cultivators can

\footnotetext{
${ }^{2}$ Pond: more than 3-5 feet depth, paddy not cultivated, vegetable cultivation is not easy, not easy to discharge water, Gher: less depth, 3-5 feet, mixed farming: rice with fish, vegetable cultivation is easy, easy water discharge
} 
combine farming and other household activities simultaneously, which is cost effective both in terms of time, money and labor. With regard to labor, most of the farms in the study area use family labor. In that sense, all of the respondents are self employed and very few farms use hired labor. Small farmers purchase fish food at the early stage of fingerling. Later on, they start feeding rice to the fishes. As a result, they do not need to buy extra food always, because they can manage it from their own share. This also ensures avoiding wastage of food. In terms of profitability, small farmers earn Tk. 0.1 million to Tk. 0.2 million per year. This is profitable for them because they invest a small amount of money in their farms.

Involvement of household's women in fish farming depends on location of the pond/gher and type of work. Women of the households in the study area are not directly involved in fish cultivation. But they play an important role in case of feeding the fishes when the pond/gher is near to their house. The reasons behind women's less participation are: (i) woman cannot be a night-guard due to security reason; (ii) maintenance of fishes is very much difficult and sometimes it takes whole day's involvement; (iii) distant location of the pond/gher.

Although fish cultivation is the major source of income in the study area, households adopt diversified sources of income to minimize shocks and vulnerabilities. For 43.33 percent of the respondents, fish cultivation is not the major source of income. They do paddy cultivation, small business, poultry rearing and laundry business. Field survey shows that 60 percent of the respondents' family members are engaged in different types of work. Their involvement ranges from rice cultivation to job holdings both in home and abroad, and to wage labors. Majority of the family members are engaged with paddy cultivation, which comprises 38.89 percent. 33.33 percent of them are engaged as migrant workers abroad, NGO workers as well as government job holders. 16.67 percent are engaged as wage laborers and rest 11.11 percent are engaged as school teachers. Field survey shows that although majority of them is engaged in paddy cultivation, households with job holders family members have financially stronger position than others to fight against shocks and vulnerabilities. While looking at average family income of other family members of the respondents, it has seen that other than fish farmers, 44.44 percent of the family members contribute up to Tk. 10000 to their family; Tk. 10001-20000 is provided by 27.78 percent family members and Tk. 20001-30000 and Tk. 30000+ are provided by 16.67 percent and 11.11 percent of the family members respectively.

Field survey shows a positive correlation between experience of fish farming and volume of production. All of the respondent agree on the fact that experience affects fish production positively through upgrading technical knowledge, efficient farm management, increasing farm size and frequency of training.

Field survey shows that majority of the respondents, which is 33.33 percent have been engaged in fish farming for less than five years. In that sense they are the newly entrants in this occupation. 30 percent and 26.67 percent of the respondents have been involved in this occupation for five to ten years and 11 to 15 years respectively. Only 10 percent of respondents are engaged in this occupation for more than 15 years. Respondents opine that long time involvement helps to increase skills required for fish farming and increase the volume of production thereby. Time duration of fish farming also positively influence the level of experience, which makes difference in productivity in fish cultivation. When a farmer starts fish cultivation he faces different problems due to lack of practical knowledge. When the time passes, he can overcome those problems progressing through learning by doing method.

Field survey shows that fish cultivation changes their ownership pattern of houses, although not to a significant extent. Most of the people in the study area have little property but they try their level best to own a house. Fish cultivation helps them either to make a good profit or to supplement a significant proportion of income, which make them able to have own homestead land for 73.33 percent of the respondents at present switching from 43.33 percent of the respondents before engaging in fish cultivation. At present 26.67 percent of total respondents is living in rented or others' houses which was 56.67 percent respondents before being engaged in fish cultivation.

While fish cultivation has a significant impact on changing ownership pattern of homestead land, it does have an important role in housing pattern of the respondent households. Field survey shows that 46.67 percent of the respondents still live in kancha houses, 33.33 percent live in semi-pucca houses and rest 20 percent live in pucca houses. The reason behind this phenomenon may be as majority of the respondents are the new entrants into this occupation and are small scale cultivators, they do not have required capacity to invest a significant amount of money to build a pucca house.

Fish farming changes savings pattern of the respondents. Table 03 shows that fish cultivation alters saving behavior of the farmers in the study area. It is important to note that percentage of savers in different savings group reduces for low tiers of savings, but increases for higher tiers of savings, which ranges from Tk. 4001 to Tk. 10,000. This change captures increasing financial strength of the households after being involved in fish farming. The most significant change occurs in the group Tk. 6001- Tk. 8000, which captures 10 percent increase in respondents in this group. Other dominant groups are Tk. 4001 to Tk. 6000 and Tk. 8001 to Tk. 10,000, which capture 6.67 percent increase of the households for each savings group. 
Table 03: Changes in Savings Behavior of the Respondents

\begin{tabular}{|r|r|lr|r|}
\hline \multicolumn{1}{|l|}{ Amount } & \multicolumn{2}{|l|}{$\begin{array}{l}\text { Percentage of respondents before } \\
\text { involving in fish cultivation }\end{array}$} & $\begin{array}{l}\text { Percentage of respondents after } \\
\text { involving in fish cultivation }\end{array}$ & $\begin{array}{l}\text { Changes in } \\
\text { percentage }\end{array}$ \\
\hline $0-2000$ & 30 & 26.67 & 13.33 & Decrease by $16.67 \%$ \\
\hline $2001-4000$ & 23.33 & 20 & Decrease by $6.67 \%$ \\
\hline $4001-6000$ & 16.67 & 30 & Increase by $6.67 \%$ \\
\hline $6001-8000$ & 3.33 & 26.67 & Increase by $10 \%$ \\
\hline $8001-$ & & 10 & Increase by $6.67 \%$ \\
10000 & $\mathbf{1 0 0}$ & $\mathbf{1 0 0}$ & \\
\hline Total & \multicolumn{2}{|l}{} & & 10 \\
\hline
\end{tabular}

Source: Authors' calculation based on field survey

Like savings behavior, small scale fish farming also increases ability of the households to spend greater amount of money, which signifies comparatively higher living standard than before. After involving in fish cultivation, the number of respondents in lower expenditure class has decreased compared to higher class. Greater number of households shifts to higher expenditure class, which is Tk. 25001 to Tk. 30000. This group captured an increase in respondent households by 13.34 percent. Subsequent classes capture the increase in respondent households by $6.67,3.33$ and 3.33 percent respectively. Higher expenditure class ranges from Tk. 45001 to Tk. 50000 captures no change in the percentage of households. Lower expenditure class ranges from Tk. 1001 to Tk. Tk. 5000, Tk. 5001 to Tk. 10000, Tk. 10001 to Tk. 15000 and Tk. 15001 to Tk. 20000 capture decrease in number of respondents by 3.33 percent, 10 percent, 10 percent and 3.33 percent respectively. No change has been occurred in the expenditure class Tk. 20001 to Tk. 25000.

Table 04: Changes in Expenditure Pattern of the Respondents

\begin{tabular}{|r|r|r|c|}
\hline $\begin{array}{l}\text { Monthly } \\
\text { expenditure }\end{array}$ & $\begin{array}{l}\text { Percentage of respondents } \\
\text { before involving in fish } \\
\text { cultivation }\end{array}$ & $\begin{array}{l}\text { Percentage of respondents } \\
\text { after involving in fish } \\
\text { cultivation }\end{array}$ & Changes in percentage \\
\hline $1001-5000$ & 13.33 & 10 & Decrease by $3.33 \%$ \\
\hline $5001-10000$ & 26.67 & 16.67 & Decrease by $10 \%$ \\
\hline $10001-15000$ & 23.33 & 13.33 & Decrease by $10 \%$ \\
\hline $15001-20000$ & 10 & 6.67 & Decrease by 3.33\% \\
\hline $20001-25000$ & 6.67 & 6.67 & No change \\
\hline $25001-30000$ & 3.33 & 16.67 & Increase by $13.34 \%$ \\
\hline $30001-35000$ & 3.33 & 10 & Increase by $6.67 \%$ \\
\hline $35001-40000$ & 6.67 & 10 & Increase by $3.33 \%$ \\
\hline $40001-45000$ & 3.33 & 6.67 & Increase by 3.33\% \\
\hline $45001-50000$ & 3.33 & 3.33 & No change \\
\hline Total & $\mathbf{1 0 0}$ & $\mathbf{1 0 0}$ & \\
\hline
\end{tabular}

Source: Authors' calculation based on field survey

Income from fish farming has an important contribution to support for children's education and health condition. In the study area most of the respondents are not highly educated, but they can well afford their children's education. As 46.67 percent of the respondents belong to the age group 26-45, all they have either school or college going children. On an average every households have two school going children. Maximum number of school going children in the households is four. Some children admitted to school this year and some are studying in colleges and universities. Most of the respondents opine that income from fish farming is helpful in financing education for their children. Because during harvesting period, selling fish at a greater volume ensures a handsome amount of money at their hand, which may be useful for maintaining educational expenses at one point of time. Apart from this, income from fish farming also contributes to finance medical expenses. Fish farming ensures a flexible source of cash money in times of emergency for the small scale pond fish cultivators. When any of the family members get sick, they simply put net to the ponds, catch fishes and go to the market for selling. Smooth flow of cash makes them able to get better medical facilities from hospitals and clinics. In that sense, this type of small scale pond fish culture helps to reduce households' health related shocks and vulnerabilities.

Most importantly, fish cultivation is particularly helpful in increasing accessibility to households' protein consumption. Before involving in fish cultivation they had to buy fish from the market but now their frequency to buying fish from the market is highly reduced and even become zero for some of the respondents. Following Table compares per capita fish consumption before and after fish farming. It shows that maximum number of households consumed up to five $\mathrm{kg}$ fish before involving in fish cultivation. After involving in fish cultivation, only three households consume up to five $\mathrm{kg}$ of fish. Following table also shows that greater number 
of households now consume greater amount of fish and significant change occurred in case of consuming 16 to $20 \mathrm{~kg}$ of fish.

Table 05: Information about Monthly Fish Consumption

\begin{tabular}{|l|l|r|}
\hline $\begin{array}{l}\text { Amount of fish consumed } \\
\text { (In kg./month) }\end{array}$ & $\begin{array}{l}\text { Number of households before involving in } \\
\text { fish cultivation }\end{array}$ & $\begin{array}{l}\text { Number of households after } \\
\text { involving in fish cultivation }\end{array}$ \\
\hline $0-5$ & 10 & 3 \\
\hline $6-10$ & 7 & 6 \\
\hline $11-15$ & 7 & 9 \\
\hline $16-20$ & 4 & 8 \\
\hline $21+<$ & 2 & 4 \\
\hline Total & $\mathbf{3 0}$ & $\mathbf{3 0}$ \\
\hline
\end{tabular}

Source: Field Survey, 2013

In addition to this, small scale fish cultivation also helps to save households' expenditure in terms of entertaining the guests. It supports household economy during social occasions for example, marriage, family gatherings and other social affairs.

\section{Problems faced by the fish cultivators}

Continuing pond fish culture requires a good technical knowledge on pond management, frequency of feeding, quality of fish food and fingerlings, harvesting time of fish etc. All of the respondents in the study area have inadequate knowledge regarding modern pond management. Lack of quality fish fry and fingerlings is another major obstacle the farmers face in the study area. 63 percent of the farmers opine that extension service of government and information regarding fish farming from the NGOs both are poor in the study area. Formal source of credit is not easily accessible in the area. As a result, farmers suffer from inadequate finance in times of need. Sometimes they collect loan from informal sources at a very high rate of interest. And all of the farmers opine that high price of fish food is one of the major obstacles to fish growth. Fish cultivators in the study area reported that prevalence of fish disease is acute in their farms. More than 50 percent of the farmers mention that unavailability of balanced feed material is an important barrier to them. Another major problem captured by the study is marketing of the fish in the study area. The farmers sell their fishes in the local market, which offers minimum price to them. Because purchasing power of the local consumers is poor. District market offers higher prices, but with their small amount of fish, small scale fish cultivators could not be able to travel to nearby district market due to high transport cost.

\section{Conclusion}

Present study explores high potentiality of small scale fish farming due to geographical setting of the study area and cost advantage of the farmers. The factors which provide a competitive edge of small scale fish farming in this region over other regions are abundance of water bodies, physical proximity of the farms to the homesteads, family labor based production, self source of food supply and women's participation in fish farming. In addition to this, income from fish farming alters expenditure and saving behavior of the households. Most importantly, it ensures a smooth flow of cash in hand at the time of emergency medical expenses and financing educational expenses for their children.

Farmers in the study area have been suffering from inadequate technical knowledge on pond management, poor extension services, and poor quality fish fry and fingerlings. Present study finds that one of the most important barriers of small scale fish cultivation in the study area is lower price of fish in the local market, which poses a threat to maintain fish farming as a sustainable livelihood option. Present study fails to explore this issue in detail due to inadequate time. Detail investigation was also needed on some other major issues, for example, system of pond management, production and marketing of fish, role of fish farming to reduce household shocks and livelihood pattern of the fish cultivators in the study area. In spite of these limitations, this study is helpful enough to unveil the importance of fish farming in addressing household shocks and in supporting household economy. Considering the importance of fish farming in the area, present study suggest government and nongovernment organizations to ensuring efficient marketing, expanding training program and ensuring supply of quality fish fry and fingerlings.

\section{References}

[1] BOBLME, Marine \& Coastal Fisheries Resources, Activities and Development in Bangladesh: Relevance to BOBLME Project, Bay of Bengal Large Marine Ecosystem (BOBLME) Project, Bangkok, Country Report (Bangladesh) No. 09, 2009, 3-5.

[2] B. Belton, M. Karim, S. Thilsted, K.M.E. Jahan, W. Collis, and M. Phillips, Review of aquaculture and fish consumption in Bangladesh, Studies and Reviews, No. 2011-53, The WorldFish Center, Penang, Malaysia, 2011, 5, Available at: http://www.scribd.com/doc/81424774/Review-of-Aquaculture-and-Fish-Consumption-in-Bangladesh (Accessed on 09th January 2013). 
[3] FAO, National Aquaculture Sector Overview. Bangladesh, Food Agriculture Organization (FAO), Fisheries and Aquaculture Department, Rome, 2005, 1.

[4] FAO, The State Of World Fisheries and Aquaculture 2012, Food Agriculture Organization (FAO), Fisheries and Aquaculture Department, Rome, 2012.

[5] M.H. Chowdhury, and K.L. Maharjan, Pond Fish Production through People's Participation in Rural Bangladesh, Journal of International Development and Cooperation, 7(2), 2001, 11-28.

[6] G.D. Graaf, and A. Latif, Development of Freshwater Fish Farming and Poverty Alleviation-A Case Study from Bangladesh, Aquaculture Asia, VII(2), 2002, 5-7.

[7] DOF, National Fisheries Strategy and Action Plan for the Implementation of the National Fisheries Strategy, Department of Fisheries (DOF), Ministry of Fisheries and Livestock, Dhaka, 2006.

[8] M.M. Dey, M.L. Bose, and M.F. Alam, Recommendation Domains for Pond Aquaculture. Country Case Study: Development and Status of Freshwater Aquaculture in Bangladesh. WorldFish Center Studies and Reviews No. 1872. The WorldFish Center, Penang, Malaysia, 2008, 7-8, Available at: http://www.worldfishcenter.org/resource_centre/WF_1104.pdf.

[9] M.G. Hussain, Freshwater fishes of Bangladesh: Fisheries, Biodiversity and Habitat, Aquatic Ecosystem Health \& Management, 13(1), 2010, 85-93.

[10] M.A. Rahman, A. Haque, and S.M.A. Rahman, Impact of Fish Farming on Household Income: A Case Study from Mymensingh District, Journal of Social Sciences, 7(2), 2011, 127-131.

[11] I. Hossain, C. Siwar, M.B. Mokhtar, M.M. Dey, and A.H. Jaafar, Socio-economic Condition of Fishermen in Seasonal Floodplain Beels in Rajshahi District, Bangladesh, Research Journal of Social Sciences, 4, 2009, 74-81.

[12] M.A. Sarker, A.H. Chowdhury, and Y. Itohara, Entrepreneurships Barriers of Pond Fish Culture in Bangladesh-A Case Study from Mymensingh District, Journal of Social Sciences, 2(3), 2006, 68-73.

[13] D. Battacharya, M. Rahman, and M.A. Khatun, Environmental Impacts of Trade Liberalization and Policies for the Sustainable Management of Natural Resources A Case Study on Bangladesh's Shrimp Farming Industry, UNEP/99/3, United Nations Environmental Program (UNEP), New York and Geneva, 1999.

[14] Banglapedia, Batiaghata Upazila, [online] Available at: http://www.banglapedia.org/HT/B_0351.HTM, 2006. (Accessed on 21th January 2013).

[15] FOBUP, Fisheries Office of Batiaghata Upazila Parishad, 2013. 